\title{
Instilling Religious Moderation Value in ELT through Cross-Cultural Understanding Course
}

\author{
Nirwana Nirwana and Waode Surya Darmadali \\ Universitas Islam Negeri Alauddin Makassar, Makassar, Indonesia \\ nirwana.nirwana@uin-alauddin.ac.id
}

\begin{abstract}
ARTICLE HISTORY
Received : 12 May 2021

Revised : 18 May 2021

Accepted : 18 June 2021
\end{abstract}

\section{KEYWORDS}

English Language Teaching (ELT)

Cross-Cultural Understanding (CCU)

Radicalism

Religious Moderation Value

Indonesia

Religion

Islam

Tolerance

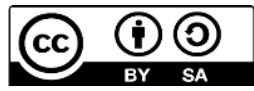

\begin{abstract}
Religious moderation has become a new and unique issue discussed by the Ministry of Religion of the Republic of Indonesia. Universities are held to be a platform for promoting religious moderation through the learning process. Integrating religious moderation in the learning process is the main alternative to increase understanding of religious moderation in educational institutions, but there are only a small number of research and technical guidelines for subjects with a religious background such as Islamic religious education. Therefore, this study intends to instill religious moderation values in English language learning through cross-cultural understanding. The CCU course is suitable for negotiating an understanding between cultures and religions, especially in the context of the multicultural society of Indonesia. This research used a descriptive qualitative method, instruments being analysis sheets of RPS documents, research rubrics, and student learning outcomes in the CCU course, library research to obtain more detailed information on the value of religious moderation, field notes on observations in class; and an 8-item questionnaire. Results reveal that universities integrate religious moderation values, such as tolerance, national commitment, accommodating to the local culture, and anti-violence, into the learning process. The researcher connected religious moderation values with learning outcomes of CCU and implemented it in the learning process by using some methods such as group presentation, debating, watching a movie. This study proved that instilling religious moderation value through CCU course improved the students' values, understanding and awareness of religious moderation. This study contributed to the Indonesian Ministry of Religion's mission to make Islamic higher education a place for instilling the value of religious moderation, especially to students as the nation's future leaders and generation.
\end{abstract}

\section{Introduction}

Indonesian society is diverse, covering various ethnicities, languages, religions, cultures, and social statuses that are very vulnerable to conflict (Akhmadi, 2008). Diversity can be an "integrating force" that binds society but can cause clashes between cultures, races, ethnicities, religions, and values of life (Marwa et al., 2018). Attitudes and behavior with nuances of violence by a group of people in Indonesia committed in the name of religion in recent years have been in the public spotlight (Ummah et al., 2018). As a plural and multicultural country, the conflicts in Indonesia are mostly related to religious background. Recently, several radical acts in the form of terror and suicide bombings have occurred in several areasI (Pradhan, 2021; Setyawan, 2021). According to Indonesia experienced 156 attacks from some 15 Islamist militant groups between 1981 and the end of 2016 (Fair, Hwang, \& Majid, 2020). Ironically some of the perpetrators of radical action came from educated circles (Arif et al., 2017). This calls for a serious undertaking for educational institutions, specifically Islamic higher education, to teach students the values of religious moderation to curb the current threat of radicalization among the generation.
The potential for radicalism in some educational institutions is a reminder of the importance of teaching moderate (i.e., temperate, judicious, reasonable) attitudes to society from an early age. A study conducted by the Agency for Research and Development of Religion, Semarang (BLAS) at 17 public schools located in nine cities/regencies of Central Java and the Special Region of Yogyakarta revealed that some of the students agreed with the idea of changing Pancasila (i.e., Indonesia's way of life). Another study, additionally, carried out by the Agency for Research and Development of Religion, Makassar exposed that $10 \%$ of 1,100 senior and vocational high school students demonstrated their potential of being radical groups. Lastly, Wahid Foundation and Indonesian Survey Circle (LSI) in 2016 reported $7.7 \%$ of 1,520 senior high school students in 34 Indonesia's provinces also showed the potential of committing radical actions (Tribun News, 2017). These research results illustrate that radicalism and extremism have affected the students' mindset and may endanger the existence of Indonesia that promotes unity in diversity, best illustrated with the national motto Bhinneka Tunggal Ika. 
Various endeavours need to be undertaken to deal with the issues of violence and radical or extreme actions. Understandably, as an Islam majority country, the current trend leans to this religion. Ni'am $(2015$, p. 131) asserts that several alternatives can be offered in response to the phenomena. Firstly, Islam should be presented as universal teaching that provides the guideline for peace on the earth. Secondly, there needs to be an effort to raise the action to prevent violence and terrorism. Thirdly, it is time to build the values of moderate Islam for building the Islamic character, which is democratic, open, and rational. It indicates that as the strengthening of religious moderation became profound, it is important to instill this value in students as a solution to stem the will of carrying out extreme thoughts. This is also in line with the national mental revolution movement (GNRM) as an effort to strengthen Character Education (PPK) according to the mandate of the Permendikbud number 20 of 2018 (Husna \& Thohir, 2020).

Higher education is expected to embody the vision of religious moderation in the Tri Dharma of Higher Education (Hefni, 2020)—starting from academic aspects (education and teaching), research, to community service. Academics are the main thing and have the opportunity to have the greatest impact in instilling an attitude of religious moderation in students. More specifically, academic development can be carried out by developing a curriculum, syllabus, or teaching materials and materials that have a religious moderation perspective (Islam et al., 2020). The values and practice of religious moderation can be contained in courses taught in tertiary institutions. When the principle of religious moderation is integrated into the curriculum, the target is not only students but indirectly also lecturers because they are the ones who will transform knowledge and values to students (Amin et al., 2019).

The idea that intolerant views and extremist action are only taken by citizens who have little to no education or are in poverty is no longer present, as nowadays "more education Muslims of higher income were now more likely to be intolerant than their low education, low-income counterparts," (Fair, Hwang, \& Majid, 2020, p. 5). The book published by the Maarif Institute, Keeping the Fortress of Diversity in Schools, showed three main ways of how radical understanding and intolerance penetrate the school environment; first, extracurricular activities. Second, the role of the teacher in the teaching and learning process. Third, school policies are still weak in controlling matters related to the potential of radicalism (Sutrisno, 2019).

The importance of increasing students' awareness of cultural and religious values in the learning process is the basis for this paper to integrate the value of religious moderation in English language teaching. This paper focuses on four indicators of religious moderation, which will be adjusted to the learning outcomes of cross-cultural understanding as one of the compulsory subjects in the English and Literature Department. The four indicators are national commitment, tolerance, accommodating to the local culture and against violence. In line with previous studies, the subject that is considered to have the most potential to build students' intercultural competence is the Cross-Cultural Understanding (CCU) course (Mulyono et al., 2017). CCU is a course that provides cross-cultural understanding, including cultural conflicts, cultural adaptation, and the values of cultural life. Culture, of course, is closely related to religion. In religious practice, there must be acculturation of culture, both in the form of the great tradition and the little tradition. So, to understand the way a group or nation carries out religious practices, one must also understand their culture (Bussmann, 2019).

CCU is not only taught in the English department of this selected institution but also in other departments such as the Communication department. This might mean that the strategy of building an attitude of religious moderation in higher education, specifically Islam in this study, can also be applied in other departments, as well as in other Islamic higher education that teaches CCU. The results of this study, namely the establishment of a curriculum and instruction structure that instills religious moderation value, will hopefully contribute to non-Islamic or open universities' similar endeavor to deal with the problem of terrorism in Indonesia.

\section{Literature Review}

\subsection{Religious Moderation and English Language Teaching}

Moderation, according to the big Indonesian dictionary, can be interpreted as an effort to reduce violence and avoid extremism (KBBI, Online). Moderation is also identical to the term wasathiyyah in Arabic. In his study, wasathiyyah is the antithesis of the terms liberalism, radicalism, extremism and puritanism (Zamimah, 2018). Meanwhile, wasathiyyah, according to Khaled Abu el Fadl, is a middle-ground understanding, i.e., a concept that is neither extreme to the right nor extreme to the left (Ikhsan, 2021). Moderation, according to Abdurrahman Wahid, encourages efforts to achieve social justice, which is referred to in religion as almaslahah al-'ammah. The word wasathiyyah is derived solely from Islam, which is wasathic in nature, meaning that all of its teachings are moderate (Ummah et al., 2018). As a result, be moderate in adherents must be rational from points of view, emotions, and attachments (Informasi \& Islam, 2019).

The fundamental values of religious moderation have been around for a long time. They have been applied in Indonesian society's social life, for example, an attitude of tolerance as well as tolerance and respect for differences (Wahyudi, 2018). However, the term "religious moderation" has only started to become popular since The Indonesian Ministry of Religion echoed the term through various media. Even recently, in October 2019, it published a catalogue entitled "Religious Moderation." Seeing the nation's current state, which is subject to religious conflicts, religious moderation is considered important to maintain the integrity 
of the Indonesian nation, "build a harmonious Indonesia, care for diversity and give respect to social plurality." The government, especially the Ministry of Religion, also integrated the vision of religious moderation into the Strategic Plan of the Ministry of Religion 2020-2024, which reads, "Indonesians are Religious, Moderate, Intelligent, and Excellent."

Moderation is the core teaching of religious understanding relevant in the context of diversity in all aspects, good religion, customs, ethnicity, and the nation itself (Dawing, 2017). At the level of praxis, especially the learning process, religious moderation needs to be instilled in a structured manner in students, from primary, secondary to higher education. The curriculum and teaching materials used in each academic unit need to adapt the concept of religious moderation properly so that students have the same understanding of religious moderation (Rizal, 2021). More specifically, academic development can be carried out by developing a curriculum, syllabus, or teaching materials and materials with a religious moderation perspective. The values and practice of religious moderation can be contained in courses taught in universities (Informasi \& Islam, 2019). When the principle of religious moderation is integrated into the curriculum, the target is not only students but indirectly also lecturers because they are the ones who will transform knowledge and values to students (Sutrisno, 2019). English language teaching is well suited as a vehicle for religious moderation (Rizal, 2021). However, addressing integrated themes and conflict resolution skills into daily classroom practice is still difficult to adjust. Hence, the current study's purpose was to establish a curriculum and instruction structure based on the subject skills and methodologies involved in a pro study. The basic premise here is that such a framework would help English lecturers organize their thinking and thus facilitate a link between religious moderation and classroom practice.

\subsection{Religious Moderation in CCU}

Facing radicalism is necessary empowerment of religious-based civil society organizations for commitment strengthening nationality; role enhancement religious, social and political leadership in educational institutions in strengthening and empowering harmony religionnationality. Widodo (2019) In educational institutions, apart from integrating religious moderation in religious subjects as an effort to fight radicalism, it also needs to integrate with various general subjects because religious moderation can be used as a new approach in counteracting radicalism. Widodo (2019) Concerning that, within the scope of the Department of English Language and Literature, Faculty of Adab and Humanities, Alauddin Islamic State University of Makassar, the subject that is considered the most potential to be

\footnotetext{
${ }^{1}$ According to an anthropologist, Robert Redlife, the great tradition is a religious practice that refers directly to and is closer
}

developed to build students' religious moderation is CrossCultural Understanding (CCU).

$\mathrm{CCU}$ is a course that provides cross-cultural understanding, including cultural conflicts, cultural adaptation, and the values of a culture's life (Natia Davitishvili, 2017). Through the Cross-Cultural Understanding course, the lecturers are expected to be able to transfer the values of tolerance in religion through the Communicating Across Cultural and Cross-Cultural Conflict and Adjustment chapters contained in this course. Because in this chapter, students will be given learning related to understanding in communicating across cultures and overcoming cultural conflicts that occur by making adjustments to the existing cultural diversity (Mulyono et al., 2017).

Culture cannot be separated from religion because both of them have an interrelated relationship. For example, in religious practice, there is also acculturation of culture, both in the form of the great tradition and the little tradition ${ }^{1}$. Meanwhile, developing culture cannot be separated from the understanding and practice of religion in the community. Thus, the approach to understanding the way a group or nation performs religious practices, that is, must also understand their culture. Therefore, in teaching CCU courses, it is very suitable to develop the concept of religious moderation. Cross-Cultural Understanding is one such subject that discusses foreign cultures, understand other people's different cultures. Cross-Cultural Understanding also discusses life - the life of westerners, their characters, culture, their daily ways, how they value their time, the values in western countries, how education in other countries, and how other countries develop (Mulyono et al., 2017; Tuzel \& Hobbs, 2017). Understanding the way a group or nation carries out religious practices, understanding their culture is one thing that must be done. Through the CCU course, lecturers are expected to transfer the values of tolerance in religion through the Communicating Across Culturals and Cross-Cultural Conflict and Adjustment chapters contained in this course. Because in this chapter, students will be given learning related to understanding across cultures and overcoming cultural conflicts that occur by making adjustments to the existing cultural diversity. Recognition of the pluralistic existence of cultures within geographical borders calls for education to improve the desirability of diversity and to create understanding. Such awareness subsequently makes foreign language teaching scholars conscious that language is closely related to culture (Diem \& Abdullah, 2020).

\section{Method}

This study uses a qualitative research design that emphasizes the description of the continuity of the implementation of character education in terms of both the

to the tradition or culture of origin of the religion - for example, Islam refers to the Arabic tradition. 
RPS design and the implementation of learning for crosscultural understanding courses. Silver argues that evaluation research is used by considering the effectiveness of old and new programs and the steps in creating some results or changes (Natri, 2015). This research was conducted in class AG 1/2, the fourth semester, English and Literature study program of UIN Alauddin Makassar, with a total number of 38 participants.

There are several instruments used in this research, namely (a) analysis sheets of RPS documents, research rubrics, and student learning outcomes in the CCU course; (b) library research to obtain more detailed information on the value of; (c) field notes, which are made when the researcher makes observations in class; and (d) a questionnaire as an evaluation instrument to see student responses in the CCU course with the encouragement of religious moderation value.

Data collection in this study consisted of several activity procedures, namely (1) collecting literature and teaching materials; (2) Focus Group Discussion with speakers, lecturers, and students of the English and literature study program regarding the encouraging of religious moderation value toward CCU course; (3) designing RPS which is consisting of moral education framework, assessment rubrics, and teaching materials in the form of PowerPoint; (4) carry out the learning process as well as observation; and (5) distributing questionnaires as a form of evaluation.

Data analysis was carried out in a descriptive qualitative manner and through several steps. Then the data interpretation is carried out through a comparison of theory and previous findings related to the research. The data analysis steps that would be used are data collection, data reduction as a process of selecting, focusing, and transforming rough data, presenting data including descriptions of data extract exposure, and drawing conclusions, namely techniques where the researcher must conclude the answer to the problem formulation by considering the results of the instrument and process during the research and linking with related theories that are used as a reference.

\section{Results}

\subsection{Adjusting Learning Outcome of $\mathrm{CCU}$ with Religious Moderation Value}

Cross-Cultural Understanding is a course taught to English language teaching. However, over time, such as the number of hoax information (not proven true) that can divide the unity, the role of the CCU is not limited to linguistic aspects but also develops at the application stage of cultural understanding concerning religious moderation, a study related to CCU's role in preventing deradicalization in higher education expressed through a questionnaire, showed that $30.2 \%$ of students agreed and $69.8 \%$ of students answered strongly agree that the Cross-Cultural Understanding course teaches tolerance which in the future can reduce radical movement (Mulyono et al., 2017).

Table 1. Four Indicators of Religious Moderation Value in CCU Class

\begin{tabular}{|c|c|c|}
\hline $\begin{array}{c}\text { Value } \\
\text { Indicators for } \\
\text { RM }\end{array}$ & $\begin{array}{c}\text { Learning } \\
\text { outcomes of } \mathrm{CCU}\end{array}$ & Topic \\
\hline Tolerance & $\begin{array}{l}\text { The students } \\
\text { understand and } \\
\text { improve their } \\
\text { appreciation of the } \\
\text { importance of } \\
\text { cultural differences } \\
\text { and diversity }\end{array}$ & $\begin{array}{l}\text { Cultural } \\
\text { acculturation, } \\
\text { cultural diversity, } \\
\text { and cultural } \\
\text { composition }\end{array}$ \\
\hline $\begin{array}{l}\text { National } \\
\text { Commitment }\end{array}$ & $\begin{array}{l}\text { To improve their } \\
\text { awareness of the } \\
\text { knowledge and } \\
\text { skills that are } \\
\text { needed for } \\
\text { successful } \\
\text { communication }\end{array}$ & $\begin{array}{l}\text { Personal } \\
\text { relationship and } \\
\text { family value }\end{array}$ \\
\hline $\begin{array}{l}\text { Accommodating } \\
\text { to local culture }\end{array}$ & $\begin{array}{l}\text { To expand cultural } \\
\text { awareness of both } \\
\text { the students native } \\
\text { and target culture }\end{array}$ & $\begin{array}{l}\text { Verbal and non- } \\
\text { verbal } \\
\text { communication }\end{array}$ \\
\hline $\begin{array}{l}\text { Against } \\
\text { Violence }\end{array}$ & $\begin{array}{l}\text { Help the students to } \\
\text { identify ways to } \\
\text { avoid } \\
\text { misinterpretation in } \\
\text { their interaction } \\
\text { with people from } \\
\text { other culture }\end{array}$ & $\begin{array}{l}\text { Cross cultural } \\
\text { conflict and } \\
\text { adjustment }\end{array}$ \\
\hline
\end{tabular}

The substance of religious moderation needs to be updated and adapted. There are four indicators of religious moderation that can be included in cross-cultural understanding courses in English language teaching. Value indicators, using the right method, will provide integrated skills with certain courses (Rizal, 2021). Four indicators of religious moderation will be used, namely 1) national commitment, 2) tolerance, 3) Against violence, and 4) accommodating local culture (Ministry of Religion, 2019). These four indicators can identify how strong religious moderation is practiced in Indonesia and its vulnerability. This vulnerability needs to be recognized to identify and take the right steps to strengthen religious moderation in the learning process.

In this study, the integration of religious moderation was carried out more specifically into CCU courses. Therefore, it is necessary to make learning outcomes in the CCU course syllabus as a reference so that the adjustment of the framework can be more precise, based on clear stages and time. Learning outcomes of the CCU course are 1) the students understand and improve their appreciation of the importance of cultural differences and diversity, 2) To improve their awareness of the knowledge and skills needed for successful communication. 3)To expand cultural 
awareness of both the students' native and target cultures. 4) Help the students to identify ways to avoid misinterpretations in their interactions with people from other cultures (Mutawakkil et al., 2020).

In describing the CCU course, these are the learning process of $\mathrm{CCU}$ following the course syllabus, which consists of 16 meetings. The first meeting is to discuss the material introduction to a cross-cultural understanding to get to know the CCU course well. The second meeting was to discuss the culture, acculturation, cultural diversity, and cultural composition in more detail. The third meeting was with the material on the relationship between language and culture and the relationship between language and culture. The fourth meeting is the importance of cultural understanding of a foreign language, which plays an important role in understanding the culture in learning foreign languages. At the fifth meeting discussing educational attitudes and understanding what culture is, students must know which attitude and behaviors well. For the next meeting, personal relationships and family values. In addition to the lecturer's material, the mid-course of the learning process will be conducted. The next class meeting includes a relaxed manner, understanding the American values and beliefs, communicating across cultural, crosscultural conflicts and adjustments, cultural verbal and nonverbal communication, and general review and feedback. For the last meeting, a final examination was generally held in the syllabus to find out the extent to which students understood CCU courses during 16 meetings in the learning process that had been discussed with the lecturer. The content of each item in this framework is adjusted to the learning outcomes and religious moderation values. In addition to the four indicators above, the values of religious moderation can be further explored from each material contained in the learning syllabus.

\subsection{The Implementation of Encouraging Religious Moderation Value in CCU Class}

Researchers as lecturers in the CCU course make introductions with students at the beginning of the meeting related to their abilities, motivation, and identity, especially the students' ethnic backgrounds. Researchers found that some of the students were interested in learning crosscultural understanding and also interesting in the issue of religious moderation even though some students had never heard about this issue.

At the following meeting, students were given the topic of the CCU course, such as cultural acculturation, cultural diversity, and cultural composition, with a cooperative learning method (group discussion). The students were given a case study from mass media and the internet related to this topic. The student was encouraged to use their critical analysis dealing with cultural diversity that caused conflict in society. The researcher provided some resources from the internet related to cultural diversity and how we must respond to diversity as a nation's wealth and can even become the strength of a country.

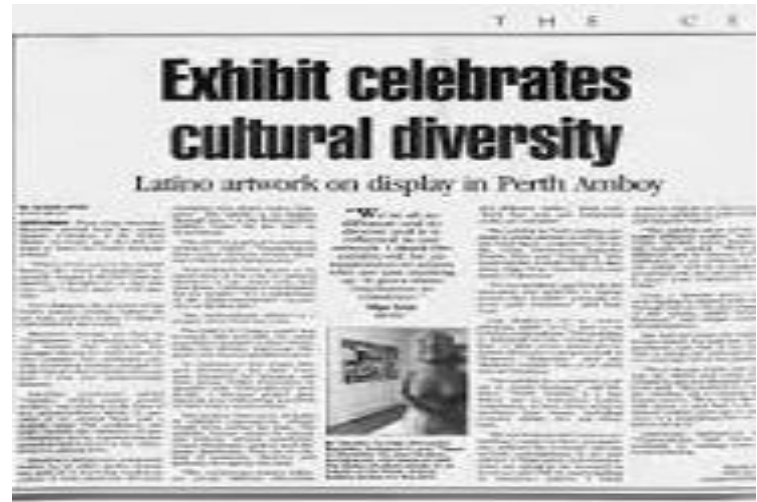

Figure 1. Newspaper as Learning media

The picture above is one of the learning media used by the lecturer to display to the students how cultural diversity is not a threat but can become a unifier in the certain country. Not only will it build awareness of national and crucial issues, it will also significantly sharpen students as well as the lecturers' critical thinking. Hence, the researchers recommend that lecturers strive to use up-to-date materials, using the popular cases as a general introduction and the newer, "hot topic" cases for discussions and projects, much like how it is commonly done in high school and debate societies (Wahyuni et al., 2020).

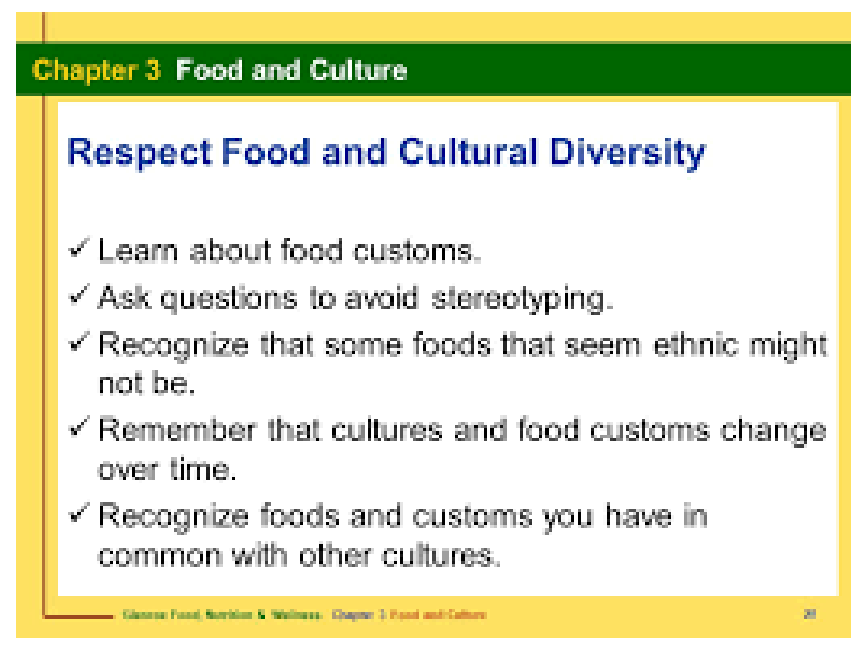

Figure 2. Teacher Materials in the classroom

In this material, the lecturer shows how to build intercultural communication in different contexts, such as food, movie, and other cultural identities. The value of religious moderation that can be encouraged in this meeting was tolerance. The value of tolerance is in line with CCU learning outcomes related to the importance of cultural differences and diversity. What happens most in cultural differences is the existence of stereotypes in certain cultures, especially western culture. As western culture is prominently featured in the CCU course, lecturers need to instil an attitude of tolerance among students. This is crucial because Western culture is often talked about in the classroom to have 
very negative influences on the younger generations, which only contribute to the sense of intolerance

The next value of religious moderation that can be integrated into the CCU course is a national commitment. The related topic in the cross-cultural understanding course is personal relationships and family values. In this material, students will get material related to differences in personal relationships or family values between eastern and western cultures. They must recognize the culture and values upheld by their nation in the context of the family. The methods used are very flexible, but one can be through authentic materials or watching movies.

A value that is no less important in religious moderation, which is in line with the learning outcomes of the CCU course, is accommodation to the local culture. Learning outcomes from the CCU course, which is in line with accommodating to local culture, is expanding cultural awareness in the classroom of ELT. Cultural awareness includes a steadily increasing inner sense of the dignity of cultures, an increased appreciation of the cultures of your own and other people, and positive interest in how cultures communicate and vary, and positive interest in how cultures share and differ. Increased knowledge of culture enables learners to expand their minds, increase tolerance, and improve cultural empathy and acceptance (Shemshadsara, 2012).

The next value is against violence. Radicalism and violence arise because of the perception of injustice and threats experienced by a person or group. Perceptions of injustice and feelings of being threatened do not necessarily give birth to radicalism. It will be born if it is managed ideologically by generating hatred against groups that are considered as injustice makers and those who threaten their identity. Related to the CCU course, this value coherence with cross-cultural conflict and adjustment. Many misrepresentations occur because of a lack of understanding of cultures or religions. On this topic, the opportunity to gain expertise in understanding other cultures will be further developed.

\subsection{The Implication of Encouraging Religious Moderation Value in CCU Class}

The form of learning evaluation used in this study is in the results of questionnaires about the students' knowledge and perceptions of the implementation of religious moderation value in the CCU course. The form of evaluation is to spread out questionnaires to find out students 'perceptions of the implementation of religious moderation values and students' knowledge of religious moderation values related to the $\mathrm{CCU}$ course.

Table 2. The result of questionnaire analysis

\begin{tabular}{clcc}
\hline No & \multicolumn{1}{c}{ Statements } & Score & Conversion \\
\hline 1 & $\begin{array}{l}\text { CCU course help me to } \\
\text { understand Religious } \\
\text { Moderation }\end{array}$ & 127 & 99.22 \\
& & & \\
&
\end{tabular}

2 The Learning outcomes of

CCU course in line with

religious moderation value

3 The methods used by the

lecturer were suitable

4 The learning resources help me to comprehend the

learning outcomes or the

value of religious

moderation

5 I have known well the indicators of religious moderation value

6 I agree to share religious moderation value in my communities

7 Religious moderation value changes my perception of diversity in my country

8 I know the importance of religious moderation to be a built-in society.

\begin{tabular}{cc}
\hline Total & 649.22 \\
\hline Average & 92.74 \\
\hline
\end{tabular}

Table 2 depicts the results of the questionnaire based on the type of question. The results of the questionnaire show that students have a very good/agreeable perception of the implementation of the religious moderation value in the CCU course. The average perception score of a total of 38 students is 90,74 or are in the strongly agree category.

\section{Discussion}

Research on the integration of cultural values in English language learning has been done before, although almost all of these studies begin by studying and making relevant teaching materials so that later they can be used in the learning process. This study advances this effort by tying it with Indonesia's current goal of dealing with the threat of radicalism in universities. The results of this study found that in addition to cultural values that are imparted during English classes that will inevitably and primarily cover western culture, lecturers must strive to integrate peace education and moral education in their learning materials. This study found that peace education is conducive to a friendly atmosphere in the English language classroom where cstudents study with a positive interest, and their cooperation is on a high level. This study implies that more education materials should be devised for young English learners by educators and experts specializing in peace education, as similarly suggested by Zamalieva (2020).

In Indonesia, a few Islamic institutions, including Islamic universities or schools, integrate Islamic moderation values in English language teaching (Rizal, 2021). It is important 
considering that several studies show that the radicalization process is carried out in many educational institutions in Indonesia (Arieft al., 2017). This is also in line with the research conducted by Sas et al. (2020), that radicalized individuals are not uneducated but have often completed secondary or tertiary education. Additionally, it became clear that some extremist groups consider the school environment as an attractive recruitment place. To strengthen the role of education for sustainable development in developing countries, this study recommends that in Indonesia's process of improving equal access to education, educational instutitons must also invest in the creation of safe spaces for their students, that not only secondary but also primary and tertiary education are involved in policy strategies regarding radicalization.

Toward the implementation of religious moderation value, this study proved that four value indicators could be successfully and easily integrated into the CCU course, namely tolerance, national commitment, accommodating to the local culture, and against or anti-violence. Tolerance is an attitude to provide space and not interfere with the rights of others to believe, express their beliefs, and express opinions, even though it is different from what individuals are sure of (Natia Davitishvili, 2017). Thus, tolerance refers to being open, generous, voluntary, and gentle in accepting differences. Patience is always accompanied by respect, get different people as part of who we are, and think positively. The aspect of tolerance is not only related to religious beliefs but can be related to differences in race, gender, ethnicity, culture, and so on (Wekke, 2017).

The next indicator in this study is a national commitment, which in the Indonesian context, is a crucial indicator to see the extent to which one's views, attitudes, and religious practices have an impact on loyalty to the necessary consensus of nationality, especially concerning the acceptance of Pancasila as the state ideology, its attitude towards ideological challenges as opposed to Pancasila, and nationalism. In the perspective of religious moderation, practicing religious values is the same as carrying out obligations as citizens, as fulfilling obligations as citizens is a form of practicing religious values (Religious Ministry of Indonesia, 2019).

Then, accommodating the local culture and against violence are the two values that this study integrates into the CCU course. Religious practices and behaviours that accommodate local culture can be used to see the extent of the willingness to accept spiritual practices that accommodate local culture and traditions (Casta, 2018). Moderate people have inclinations, more friendly in taking local customs and culture in their religious behaviour, as long as they do not conflict with the principal spiritual value. The traditional diversity that is not rigid, among others, is fear of willingness to accept religious practices and behaviour that do not merely emphasize normative truth, but also take spiritual practices that are based on virtue, of course, once again, as long as these practices do not conflict with the principles of teaching religion. Some groups tend to not be accommodating to traditions and culture because practicing tradition and culture in faith will be considered an act that pollutes the purity of religion.

Radicalism and violence arise because of the perception of injustice and threats experienced by a person or group (Kusumaningputri, 2019). Perceptions of injustice and feelings of being threatened do not necessarily give birth to radicalism. It will be born if it is managed ideologically by generating hatred against groups that are considered as injustice makers and those who threaten their identity (No \& Ali, 2018).

Mainstreaming religious moderation in higher education will be effective by written guidance in the learning process. The learning planning can also be contextualized with the needs and interests of students and lecturers. In a practical context, some value in education is close to character education incorporated into the teaching of foreign languages. As developed by Albantani \& Madkur (2016), the integration can be enforced by (1) accepting the values of the character with the lesson, (2) instilling values of the name in every learning activity, (3) delivering values of the word through the teaching method used, and (4) planting and practicing values of character education through daily life.

Challenges in applying in the classroom will inevitably be encountered in the learning process. This is because religious moderation is something that is still relatively new in the context of higher education, although the development of religious moderation is always being carried out. Lecturers play an essential role in this matter; thus, lecturer qualifications are the main thing that must be fulfilled before instructing the implementation of religious moderation in the learning process.

This study stresses that the concept of religious moderation is not evenly recognized in all religious education institutions in each religion. However, the values of religious moderation are substantively found in each faith's teachings in various forms and terms, following the core and principal teachings of it. Individually, a moderate attitude in religion has not become an everyday awareness to be used as the necessary capital to initiate and build a much tighter and productive socio-religious relationship, both for religious purposes itself and broad national goals. Moderation is carried out as limited to the personal needs and beliefs of religious adherents; it has not yet become a joint movement that can affect the way of public views in general to create a harmonious life (Kusumaningputri, 2019).

The last, based on the results of the questionnaire, students showed a spirit, good response, and positive attitude towards the encouraging of religious moderation value in the $\mathrm{CCU}$ course. Both the method and resources that the lecturer used in the learning process helps the students in gaining an understanding of religious moderation through the CCU course. 


\section{Conclusion}

Based on the exposure to the results of the research and discussion above, there four indicators of religious moderation value that relate to the learning outcomes of the $\mathrm{CCU}$ course are tolerance, national commitment, accommodating to the local culture, and against violence. Then, it can be concluded that the process of encouraging religious moderation value, which includes planning, implementation, and evaluation of learning, has not encountered such a big obstacle. In the planning process, the researchers adjusted the learning outcome of CCU with the value of religious moderation. In the implementation process, the lecturer used several methods such as watching movies, group presentation. Last but not least, in the evaluation stage, the study concluded that the students got more understanding toward the religious moderation value that should be implemented in their daily life. Therefore, all components of Islamic higher education can maximize their role in spreading the value of religious moderation to the wider community.

\section{References}

Akhmadi, A. (2008). Moderasi Beragama Dalam Keragaman Indonesia Religious Moderation in Indonesia's Diversity. Jurnal Diklat Keagamaan, 13(2), 45-55.

Amin, M. I., Haryani, T. N., Arifah, N. H., \& Husna, A. M. (2019). Islamic Education in Supporting Deradicalization: A Review of Islamic Education in Pondok Pesantren. Nadwa, 12(2), 259. https://doi.org/10.21580/nw.2018.12.2.2581

Bussmann, R. (2019). Great and Little Traditions in Egyptology. 10. Ägyptologische Tempeltagung: Ägyptische Tempel Zwischen Normierung Und Individualität, 2014 (August 2014), 37-48. https://doi.org/10.2307/j.ctvc5pfjr.7

Casta, J. (2018). Pedagogic Practices in ESL Teaching: A Case of Religious and Secular-ESL Classrooms. SSRN Electronic Journal. https://doi.org/10.2139/ssrn.3118817

Diem, C. D., \& Abdullah, U. (2020). Promoting multiculturalism: Teachers' English proficiency and multicultural education in Indonesia. Indonesian Journal of applied Linguistic. (1), 46-58.

Fair, C. C., Hwang, J. C., \& Majid, M. A. (2020). The pious or the doctrinaire? who supports suicide terrorism in Indonesia?. Asian Security, 16(3), 281-303.

Harto Kasinyo. (2019). Pengembangan Pembelajaran PAI berwawasan Islam Wasatiyah : Upaya membangun sikap moderasi beragama peserta didik. At-Ta'lim, jurnal media informasi dan pendidikan Islam. 18(1), 89-110.

Hefni, W. (2020). Moderasi Beragama dalam Ruang Digital: Studi Pengarusutamaan Moderasi Beragama di
Perguruan Tinggi Keagamaan Islam Negeri. Jurnal Bimas Islam, 13(1), 1-22. https://doi.org/10.37302/jbi.v13i1.182

Husna, U., \& Thohir, M. (2020). Religious Moderation as a New Approach to Learning Islamic Religious Education in Schools. Nadwa, 14(1), 199-222. https://doi.org/10.21580/nw.2020.14.1.5766

Islam, A., Di, P. A. I., Tinggi, P., \& Swasta, U. (2020). Aziz, Yahya. Penguatan Mata Kuliah Pendidikan Agama Islam di Perguruan Tinggi Umum. Jurnal Sosial Humaniora. Vol. 4 No. 2. November 2011. 6(2).

Kusumaningputri, R. (2019). Responding to Islamic religious conducts : Situating morality through critical reading literacy task on cartoons for Indonesian EFL muslim learners. Indonesian Journal of applied linguistic $9(1), \quad 210-218$. https://doi.org/10.17509/ijal.v9i1.11381

Marwa, M., Cahyono, B. Y., Latief, M. A., \& Prayogo, J. A. (2018). ICC Assessments and Objectives Grounded from Indonesian English Teachers' ELT Practices in Higher EFL Education: Are they Visible and Worthy. Journal of Applied Linguistics and Language Research, 5(4), 92-108.

Mohd Arif, M. I. A., Rahman, N. H. A., \& Hanapi, H. (2017). Madrasah Education System and Terrorism: Reality And Misconception. International Journal of Educational Best Practices, 1(1), 83. https://doi.org/10.31258/ijebp.v1n1.p83-92

Mulyono, T., Rifanan, A., \& Muktiati, S. (2017). CrossCultural Understanding dan Deradikalisasi Agama: Studi Kasus Mahasiswa Pendidikan Bahasa Inggris IAIN Surakarta. Academica: Journal of mutidiciplinary studies. Vol 1no 1 (2017).

Mutawakkil, M. H., Magister, P., Agama, P., Islam, U., Maulana, N., \& Ibrahim, M. (2020). Nilai-Nilai Pendidikan Moderasi Beragama Untuk.

Natia Davitishvili. (2017). Cross-Cultural Awareness and Teaching English as a Second Language in the Context of Globalization. Sino-US English Teaching, 14(9). $8072 / 2017.09 .003$

No, V., \& Ali, F. (2018). Incorporating Values of Moderate Islam for the 21st Century Learners in an English as a Foreign Language Class Edukasia Islamika Jurnal Pendidikan Islam.. 3(1), 18-31.

Pradhan, D. (2021). Globalization of Religious Extremism and Terrorism in Indonesia. Sospol: Jurnal Sosial Politik, 7(1).

Rizal, D. (2021). Islamic Moderation Values within ELT in a Higher Education Context. https://doi.org/10.4108/eai.14-10-2020.2303850 
Sas, M., Ponnet, K., Reniers, G., \& Hardyns, W. (2020). The role of education in the prevention of radicalization and violent extremism in developing countries. Sustainability (Switzerland), Multidiciplinary scientific journal 12(6). https://doi.org/10.3390/su12062320

Setyawan, Y. B. (2021). Terrorism and religious fundamentalism: A biblical-Christian perspective for peacebuilding in Indonesia. International Review of Mission, 110(1), 27-40.

Shemshadsara, Z. G. (2012). Developing cultural awareness in foreign language teaching. English Language Teaching, 5(3), 95-99. https://doi.org/10.5539/elt.v5n3p95

Sutrisno, E. (2019). Aktualisasi Moderasi Beragama di Lembaga Pendidikan. Jurnal Bimas Islam, 12(2), 323-348. https://doi.org/10.37302/jbi.v12i2.113

Tuzel, S., \& Hobbs, R. (2017). The use of social media and popular culture to advance cross-cultural understanding. Comunicar. Media Education Research Journal, 25(1).

Ummah, D. N., Rohmatin, E. A., \& Hasanah, B. (2018). Pentingnya Moderasi Rahmatal lil Alamin Pendahuluan Pembahasan Tidak Terlalu Ekstrim Ke Kanan dan Ke Kiri. Jurnal Diklat Keagamaan, Vol. 13 , no. 2 .

Wahyudi, W. E. (2018). Tantangan Islam Moderat di Era Disruption. Proceedings of Annual Conference for Muslim Scholars, Series 2, 922-928. http://proceedings.kopertais4.or.id/index.php/ancoms /article/view/192

Wahyuni, S., Qamariah, H., Syahputra, M., Yusuf, Y. Q., \& Gani, S. A. (2020). Challenges and solutions to develop critical thinking with the British Parliamentary Debate System in EFL classrooms. International Journal of Language Studies, 14(3).

Wekke, S. (2017). Religious Education and Tolerance: Learning Process in High School of Religious Education and Tolerance : Learning Process in high school. Journal Civic Education, 3(3), 137-141.

Widodo, P. (2019). Moderasi Agama dan Pemahaman Radikalisme di Indonesia. Jurnal Teologi agama Kristen. 15(5), 9-14.

Zamalieva AI (2020) Promoting Peace Education via Language Teaching. In: Gafurov I, Valeeva R (Eds) VI International Forum on Teacher Education, Kazan Federal University, Russia. May 27 - June 9, 2020. ARPHA Proceedings 3: 28852893. https://doi.org/10.3897/ap.2.e2885
Zamimah, I. (2018). Moderatisme Islam Dalam Konteks Keindonesiaan. Jurnal Al-Fanar, 1(1), 75-90. https://doi.org/10.33511/alfanar.v1i1.12 